\title{
Phenomenological Approach in Gauging Native Community Quality of Life
}

\author{
N. Lyndon ${ }^{1}$, Salfarina Abd. Gapor ${ }^{2}$, Er A. C. ${ }^{1}$, M. J. Mohd Fuad ${ }^{1}$, S. Selvadurai ${ }^{1}$, A. R. Mohd Helmi ${ }^{3}$ \& R. \\ Zaimah $^{1}$ \\ ${ }^{1}$ School of Social, Development and Environmental Studies, Faculty of Social Sciences and Humanities, \\ Universiti Kebangsaan Malaysia, Malaysia \\ ${ }^{2}$ School of Social Sciences, Universiti Sains Malaysia, Malaysia \\ ${ }^{3}$ School of Media and Communication Studies, Faculty of Social Sciences and Humanities, Universiti \\ Kebangsaan Malaysia, Malaysia \\ Correspondence: N. Lyndon, School of Social, Development and Environmental Studies, Faculty of Social \\ Sciences and Humanities, Universiti Kebangsaan Malaysia, Bangi 43600, Selangor, Malaysia. Tel: \\ 60-3-8921-4212. E-mail: novellyndon@gmail.com
}

\author{
Received: March 14, 2013 Accepted: March 22, 2013 Online Published: April 28, 2013 \\ doi:10.5539/ass.v9n6p30 URL: http://dx.doi.org/10.5539/ass.v9n6p30
}

\begin{abstract}
The main objective of this study is to get a clear understanding of the quality of life of the Bidayuh community through the world view of the Bidayuh community. The clear understanding of the concept of quality of life from the world-view of Bidayuh community will give an accurate development and a proper community development program for this community. This research has drawn on the phenomenological approach utilising abductive logic based on idealist ontology and constructionist epistemology. This study was conducted in the Serian District, Sarawak which is one of the four districts under the administration of Samarahan Division. The size of the sample for this study was 50 which are achieved through the continuous support toward measurement or the criteria on theoretical saturation. Data in this study was collected using the technique of in-depth interview and informal group discussion. The themes of basic needs and accessibility to infrastructure facilities in their environment became the main choice of the Bidayuh community. Suggestions for further action are addressed to the development agencies, development planners and policy makers so as to give more emphasis on the bottom-up approach and the needs of the native community in community development program.
\end{abstract}

Keywords: native community, phenomenological approach, quality of life

\section{Introduction}

Previous research clearly shows that the ineffectiveness of a development programme to improve the quality of life of the rural community is often associated with the attitude of the planners who fail to understand the life's needs and aspirations of the target group as well as the world realities of their social lives (Shamsul, 1977; Katzner, 1979; Fishers, 1998; Horowitz, 1998; Sen, 1999; Van Wicklin, 2001). In addition, the objective of a development plan typically highlights two things. First, the planners are also the economists or those who have received training in the field of economics, and second is the tendency toward the approach to Rostow Theory, that is the changes from the traditional to modernisation, which is characteristically unilinear without taking into consideration its suitability to a community particularly from the socio-cultural aspect and acceptance toward modernism (Myrdal, 1970; Shamsul, 1977; Sanjaya et al., 2005). The main focus of development programmes is the economic development plan that only prioritises economic growth dan social changes as a measure of successful developments (Shamsul, 1977; Sen, 1993). This situation further led to the development programmes that are planned by the government to improve the quality of life of the community which often experiencing failures (Ngidang \& Abdul, 1999; Ngidang, 2002). As the result, the rural community has been portrayed by Western orientalists as a community that has cultural values of laziness, hard to change, not highly ambitious, submissive to fate, and has traditional characteristics that are considered an impediment to the development (Grijpstra, 1971; Abdul Rashid, 1990; Walker, 1998; Minos, 2000; Madeline, 2004). However, this depiction in actuality can be disputed. 
Research by economists, anthropologists, social psychologists and sociologists regarding the concept of quality of life often uses different orientations and concepts (Novel, 2010). Sociological and anthropological studies focused on developmental construct methodology based on conflict and balance oriented models in order to look at the concept of the quality of life, while economic studies emphasised economic growth and social change based on Rostow's construct methodology, Stages of Economic Growth. Social psychology studies placed emphasis on the cognitive and emotional aspects to discuss the concept of the quality of life by using the free will environment which is an environment where social actors are determined to be free from poverty. This paper seeks to understand the meaning of the quality of life of the rural Bidayuh ${ }^{1}$ community based on ontological interpretation where the social actors define their realities under the social environment and practical barriers faced by them in their daily lives.

\section{Methodology}

\subsection{Description of Study Area}

This study was conducted in the district of Serian, which comprises of 261 kampungs or villages. Serian District is under the administration of Samarahan Division and administered by a Resident after Samarahan was officially designated as a Division on 1st January 1987 (Sarawak, 2004). Each district is administered by a District Officer. Meanwhile, Sub Districts are governed by the Administrative Officer (Pejabat Residen Samarahan, 2009; Unit Pentadbiran, Jabatan Ketua Menteri, 2010) Serian District is located about 64 kilometres south of Kuching City and has several sub-districts within it, one of it is the sub-district Tebedu which is the Main Gateway (International Border Crossing) for Malaysia/Indonesia (in Sarawak) (Sarawak, 2004). The District of Serian covers an area of 2,040 sq km consisting of 13 zones with a total population of 80,061, of which 40,085 (50.06\%) are males and 39,976 (49.9\%) are females (Sarawak, 2004). Out of this, only six zones are the Bidayuh areas, namely Tebedu, Ampungan, Amo, Tebakang, Kedup and Bukar. The study area for this research covers two zones or sub-districts, which are Tebedu and Kedup where the poverty programme was carried out.

\subsection{Research Design}

Phenomenological approach was used in this study. This is because the phenomenological approach suggests that, understanding the reality of life of the social actors should be through the subjective experience of the social actors that includes their views, conscience, and the attitude toward their world and themselves and not influenced by the modernization process taking place in their social environment (Blaikie, 2000; Bhaskar, 1979; Giddens, 1976). Consequently, social researchers should make interpretations of the observed reality since the social actors and social researchers are bound to each other when making interpretations. The in-depth interviews with all the informants had been conducted in Bidayuh language. Respondents in this study were identified using non-probability sampling, with a combination of judgmental or purposive sampling, snowball sampling and theoretical sampling. The data had reached saturation after 30 interviews. Data saturation is referred to as a point where the information one gets from the interviews becomes redundant (Bogdan \& Biklen, 1998). The interview process was a learning process thus, the topic discussed developed as the interviews progressed. Therefore, it was necessary to conduct a second round of interviews particularly with those who were interviewed in the early stages. The number of second-round interviews was determined based on the point when theoretical saturation was reached. A total of 50 respondents took part in this study.

\subsection{Data Collection and Timing}

Data were gathered using in-depth interviews within the period of four months. The in-depth interviews in this study involved conversations between two parties namely between the researcher and the respondents with one specific aim which is to understand the quality of life from the view of the Bidayuh community. These interviews between the researcher and the respondents focused on quality of life, daily life, their perception about life and the Bidayuh's understanding of quality of life based on their own experiences. Most of the interviews conducted took two to three hours and there were also some interviews which took longer time. All the interviews were transcribed and formatted for inclusion into the Nvivo database and were used to create categories for data indexing. Second stage interviews were also conducted with the purpose of testing intensively the categories that had been identified during the early stages of the interviews. In addition, it was also aimed in reviewing the validity of the categories that were produced in the interviews.

\subsection{Data Analysis}

There are five chains of activity that were carried out by the researcher during the data analysis process. They are as following: i) interviews that was recorded with each respondent will be copied and translated into transcript 
format; ii) before these transcripts are written or produced, the researcher will listen to the interviews that have been recorded at least twice to ensure no interviews have been omitted or neglected; iii) as soon as the transcription process is completed, each transcript or text will later be reviewed or given reconsideration and rearranged to reflect a brief description of the Bidayuh community's quality of life; iv) the data are later saved in files using different names; v) a few jargons in Bidayuh language used by the Bidayuh community in their daily lives when making desrciptions or narratives about the quality of life are maintained in original words; and finally vi) the next step that is considered very important in this study is managing the data through the categorisation process. In the process, the researcher will develop a matric table as a way to tabulate the results into a style or way that is more structured and organised. By using themes derived from the continuous comparative analysis, the researcher next tabulates specific excerpts based on the line numbers that appear in the scripts.

\section{Results of The Study and Discussion}

The rural Bidayuh community's interpretation about quality of life predominantly put across issues about basic needs and accessibility to infrastructure facilities in their environment. This matter is parallel with comments given by a few scholars such as Azahan (2007), Anuwar (2002), Abdul Kadir (2010) and Abdul Rahman (2005) who mentioned that the view of rural communities about quality of life is often influenced by self-readiness, rural development support system, rural environment, infrastructure, and accessibility to the environment that is provided in the rural area. Accordingly, the meaning of quality of life that is stated by the respondents in this study is not only a measure of the exisiting environment, but also assesses the aspects of their self-readiness and accessibility to the environment provided by the rural surroundings. Table 1 shows the ranking of the 23 themes that have been interpreted by the rural Bidayuh community as their view about quality of life. Based on the table, the themes of residence or house, income, money and savings, employment, infrastructure and public services, customary land and land grant and accessibility to agricultural produce market are the themes that have become the main choices of the rural Bidayuh community.

Table 1. Arrangement of the ranking of quality of life themes of the rural bidayuh community according to main choices

\begin{tabular}{rlr}
\hline No. & $\begin{array}{l}\text { Interpretation of quality of life themes of the Bidayuh } \\
\text { community in the rural areas }\end{array}$ & $\begin{array}{c}\text { The total of respondents who made the choice on } \\
\text { the themes (n=50) }\end{array}$ \\
\hline 1 & Residence/House & 50 \\
2 & Income, money and savings & 50 \\
3 & Employment & 50 \\
4 & Infrastructure and public services & 50 \\
5 & Customary land and land grant & 50 \\
6 & Accessability to agricultural produce market & 49 \\
7 & Spiritual, religious practice and moral being & 47 \\
8 & Health & 47 \\
9 & Education & 46 \\
10 & Children & 45 \\
11 & Family relationship & 45 \\
12 & Relationship with community members, neighbours and friends & 45 \\
13 & Welfare support & 45 \\
14 & Security & 40 \\
15 & Hope and aspirations & 30 \\
16 & Absence of debt & 25 \\
17 & Local administration and government & 20 \\
18 & Food & 15 \\
19 & Material to go through life & 15 \\
20 & Good appearance & 15 \\
21 & Participation & 10 \\
22 & Potential & 8 \\
23 & Empowerment & 5 \\
\hline
\end{tabular}


All these themes on quality of life of the rural Bidayuh community's view can be broken into seven main categories as presented in Figure 1 namely: i) security and stability; ii) community, resources and environment; iii) physical and psychological well-being; iv) family relationship; v) participation; vi) potential; and vi) empowerment. These seven categories were determined by two main factors which are importance and enjoyment of life. These categories are interconnected with each other. Therefore, the findings of this research is a bit different from the results of previous local studies carried out by Madeline (2004), Gusni (2003), Gusni and Kasim (2006), Abdul Malek (1996), Asnarulkhadi (1996) and Mohd Yusof (1990) who concluded that aspects of income and assets are the main measure of quality of life and social stratification of the indigenous communities in the rural areas. This is because the meaning of quality of life that is understood by the rural Bidayuh community is more representative of their view and involves aspects such as residence, income, infrastructure, land, accessibility, health, education, family relationship as well as relationship between the community members. As noted by Azahan (2007), the meaning of quality of life is not the measure of the existing environment, but also evaluates aspects of self readiness of the rural community and accessibility to the environment provided in the rural areas and also the view of the community about quality of life. Meanwhile, Higgs (2006) in his study on perception of quality of life of the South African community in the rural areas found that aspects of physical or psychological needs are the main needs of the rural community. The same opinion is expressed by Easterlin (2001) who concluded that aspects of income and financial situation as well as physical and psychological needs are the key indicators of the rural community's quality of life in several developing countries. In the meantime, Diener and Lucas (2000), Ravallion (2001) and Milanovic (2002) in their studies found that communities who live in the rural areas are more inclined to choose objective well-being such as material aspects and basic facilities as the main indicator in determining their quality of life.

The findings obtained by Katiman and Abd. Hamid (1996) on the development of the poorest people in Kuala Terengganu are quite consistent with the results of this study. This is because the results of their study found that even though there exists a rapid process of development in the rural areas such as land development through the opening of oil palm plantations and construction of factories, but quality of life indicators such as residence, income, employment, land, education, security, food, infrastructure and public services, relationship with community members and local administration and the government still remains as the main choice. Research conducted by Narayan et al. (2000) on the voice of the poor involving twenty three countries comprising of countries in the Middle East, South East Asia, West Asia, latin America, East Europe and the Caribbean particularly in the rural areas is also consistent with this research. Their research findings found that the view and perception of the rural communities in those countries about the quality of life are more inclined to indicators that are associated with material well-being such as food security, assets and employment and give less emphasis on issues which are subjective in nature such as freedom of speech, freedom to have access to education and skills, freedom of movement, principles of justice, integrity and human rights. This is because shortage of food supply, shortage of resources namely land for the purpose of agriculture and financial problems to meet the needs of the family members have been identified as the major problem that continuously haunts their quality of life.

This situation clearly shows that economic development through the process of modernisation is not the only condition sufficient to reduce poverty or improve the quality of life of the rural community. This is because economic development through the process of dualism is not necesarily able to reflect the existence of equitable resource distribution between the urban and rural areas, freedom from oppression, exploitation or even equal participation in the economic and political aspects (Esteva, 1985; Rahimah, 1989; Zell, 2007). Giddens in his theory of structuration states that this situation emerges because of the existence of conflict between the social practice that is understood from two different angles which is from the angle of the view of the social actors (micro structure) and from the angle of the view of the social institution (macro structure) (Giddens, 1984). Meanwhile, important aspects in measuring development like development for whom, the purpose of the community development, the form and content of community development, the method and strategy of community development are often disregarded or left behind. The interests of investors, financiers and view of the policy makers in the macro level structure are the ones prioritised.

\section{Conclusion and Implications of Research}

There are 23 types of themes and seven categories of interpretations of the rural Bidayuh community about quality of life. In terms of the ranking of the themes, residence, income, money and savings, employment, infrastructure and public services, customary land and land grants and accessibility to agricultural produce market are the themes that are the main choice of the rural Bidayuh community. This situation clearly shows that the view of the rural Bidayuh community about quality of life is constructed based on the nature of their social world life such as the 
world of common sense, the world of everyday life, the world of daily work and common realities that have been embedded for so long in their daily lives. In other words, the view of the Bidayuh community about quality of life in this study does not only depend on will alone, and is not only limited in terms of material or physical needs but also involves other needs that are subjective in nature such as cognitive, sociological and psychological. In addition, it is also closely related with helplessness or inability as well as links economic indicators with the social and environmental aspects. The implication of this research is that policy makers should give priority to the bottom up approach in the implementation of the development programme that is by taking into consideration the needs of the local community, the local culture and knowledge system itself. Future research should focus on the relationship between the views of the quality of life that is conceptualised by the policy makers with the world-view of the quality of life constructed in the structure of the local community level.

\section{Acknowledgments}

The researcher would like to thank Universiti Kebangsaan Malaysia for the provision of the Research University Grant UKM-GGPM-PLW-018-2011 which enables smooth implementation of this research and UKM-DLP-2012-030 under the leadership of the Assoc. Prof. Dr. Er Ah Choy.

\section{References}

Abdul, K. J. (2010, April 1). Poverty eradication a must for new model. Malaysian Business.

Abdul, M. I. (1996). Pembasmian kemiskinan petani padi: kajian kes di kawasan bukan jelapang padi. In S. D. Chamhuri, \& I. N. Aini (Eds.), Kemiskinan dalam arus pembangunan ekonomi Malaysia (In Malay, pp. 221-237). Bangi: Penerbit Universiti Kebangsaan Malaysia.

Abdul, R. A. (1990). The responses of farmers in two Bidayuh communities to an in situ land development programme. In V. T. D. King, \& J. G. Parnwell (Eds.), Margins and minorities: the peripheral areas and peoples of Malaysia. Hull University Press.

Abdul, R. E. (2005). Development and well-being. Bangi: Penerbit Universiti Kebangsaan Malaysia.

Anuwar, A. (2002). Industrialisasi dan pembangunan sosioekonomi di Malaysia: Pengalaman, permasalahan dan prospek masa depan. In I. D. Rokiah, M. Zaidah, \& I. Yahaya (Eds.), Industrialisasi dan modenisasi di Malaysia dan Indonesia (In Malay). Kuala Lumpur: Prentice Hall.

Asnarulkhadi, A. S. (1996). People's participation in community development and community work activities. Unpublished Doctoral Thesis, University of Nottingham. United Kingdom.

Azahan, A. (2007). Kualiti hidup dalam konteks persekitaran, akses dan kesediaan diri masyarakat bandar di Malaysia (In Malay). Bangi: Pusat Pengajian Siswazah.

Bhaskar, R. (1979). The possiblity of naturalism: A philosophical critique of the contemporary human sciences. Brighton: Harvester.

Blaikie, N. W. H. (2000). Designing social research. Cambridge: Polity Press.

Bogdan, R., \& Biklen, S. (1998). Qualitative research for education. Needham Heights, MA: Allyn \& Bacon.

Chamhuri, S., \& Aini, I. N. (Eds.). (n. d.). Kemiskinan dalam arus pembangunan ekonomi Malaysia (In Malay). Bangi: Penerbit Universiti Kebangsaan Malaysia.

Diener, E., \& Lucas, R. E. (2000). Subjective emotional well-being. In M. D. Lewis, \& Haviland (Eds.), Handbook of Emotions (2nd ed.). New York:Guilford.

Easterlin, R. A. (2001). Income and happiness: towards a unified theory. The Economic Journal, 111, 465-484. http://dx.doi.org/10.1111/1468-0297.00646

Esteva, G. (1985). Beware of participation. Development: Seeds of Change, 3, 77.

Fishers, R. J. (1998). Instutional incompatibility in community forestry: The case of Nepal. In D. J. Fox, \& R. J. Fisher (Eds.), Community organisation and government Bureaucracies in social forestry. Working paper no.22. Hawaii: Environment and Policy Intitute, East-West center.

Giddens, A. (1976). New rules of sociological method: a positive critique of interpretative sociologies. London: Hutchinson.

Giddens, A. (1984). The constitution of society: outline of the theory of structuration. Berkeley: University of California Press.

Grijpstra, B. G. (1971). Cooperation and development among the Bidayuh. Borneo Research Bulletin, 3(2), 67-68. 
Gusni, S. (2003). Komuniti Samah-Bajau di Bandar. Bangi: Penerbit Universiti Kebangsaan Malaysia.

Horowitz, M. (1998). Development and the Anthropological Encounter: A Reflective Underview. Development Anthropologist, 16(2), 44-50.

Katiman, R., \& Abd. Hamid, A. (1996). Keperluan asas, pembangunan rakyat termiskin dan pusat perkhidmatan desa: pengajaran dari Hulu Terengganu (In Malay).

Katzner, D. W. (1979). Choice and the Quality of Life. Beverly Hills:Sage Publications.

Lyndon, N., Er, A. C, Selvadurai, S., Junaidi, A. B., \& Rosniza, A. C. R. (2012). Construct of economic participation of rural native men and women. Journal of Applied Sciences Research, 8(8), 4103-4112.

Madeline, B. (2004). Towards the National Vision Policy: Review of the Economic Policy and New Development Policy among the Bumiputera Communities in Sarawak. Journal of Malaysian Studies, 21(1), 211-256.

Milanovic, B. (2002). Can We Discern the Effect of Globalization on Income Distribution? Policy Research Working Paper 2876, World Bank, Washington DC.

Minos, P. (2000). The future of the Dayak Bidayuhs in Malaysia. Lynch Media and Services, Kuching, Sarawak.

Mohd. Yusof, K. (1990). Development policies and strategies of Sarawak in relation to Malaysia's economic development. In D. A. M. M. Salleh, H. Solhee, \& M. Y. Kasim (Eds.), Sosio-economic development in Sarawak policies and strategies for the 1990s proceedings of a seminar held at Kuching, Sarawak, October 10-12, 1988 (In Malay). Angkatan Zaman Mansang (AZAM), Kuching, Sarawak.

Myrdal, G. (1970). The challenge of world poverty. New York: Pantheon.

Narayan, D., Chambers, R., Shah, M. K., \& Petesch, P. (2000). Voices of the poor crying out for change. Oxford University Press. http://dx.doi.org/10.1596/0-1952-1602-4

Ngidang, D. (2002). Contradictions in Land Development schemes: The Case of Joint Venture in Sarawak, Malaysia. Asian Pacific Viewpoints, 43(2), 157-180. http://dx.doi.org/10.1111/1467-8373.00171

Ngidang, D., \& Abdul, R. A. (1999). Rural Cooperative Societies and Community Development in Sarawak. In V. T. King (Ed.), Rural Development and Social Science Research: Case Studies from Borneo (pp. 251-267). Borneo Research Council.

Rahimah, A. A. (1989). Pengantar sosiologi pembangunan (In Malay). Kuala Lumpur: Dewan Bahasa dan Pustaka.

Ravallion, M. (2001). Growth, inequality and poverty: looking beyond averages. World Development, 29(11), 1803-1815. http://dx.doi.org/10.1016/S0305-750X(01)00072-9

Saat, G., \& Mansur, K. (2006). Permasalahan kemiskinan di kalangan suku kaum Sama-Bajau di Sabah: satu tinjauan. Konferen Antara Universiti di Borneo-Kalimantan Ke-2. Transformasi Sosial Perkotaan/Bandar Borneo-Kalimantan, Universitas Tanjungpura, Pontianak Kalimantan, Indonesia, (In Malay),13-15 Ogos 2006.

Sanjaya, A., Etsuo, Y., Masamine, J., \& Susumu, W. (2005). Empowering rural women through a community development approach in Nepal. Community Development Journal, 42, 34-46. http://dx.doi.org/10.1093/cdj/bsi064

Sarawak. (2008). Population and housing census of Malaysia. Department of Statistics. Kuala Lumpur: Gov't Printing Office.

Sen, A. (1993). Capability and Well-Being. In M. D. Nussbaum, \& A. Sen (Eds.), The Quality of Life (pp. 30-53). Oxford: Clarendon Press. http://dx.doi.org/10.1093/0198287976.003.0003

Sen, A. (1999). Development as freedom. Oxford, UK: Oxford University Press.

Shamsul, A. B. (1977). Rancangan Malaysia Kedua: Satu Penilaian dan kritikan teoritis (In Malay). Akademika, Bil.10.

Van Wicklin, W. A. (2001). The World Bank's experience with local participation and partnerships: Lessons from and OED evaluation. Retrieved January 9, 2003, from http://www.undp.org/csopp/CSO/NewFiles/docemppeople1.html

Zell, C. M. (2007). The movement of the landless rural workers: issues of development in Brazil. Journal of Comparative Social Welfare, 23(1), 61-68. http://dx.doi.org/10.1080/17486830601099952 